\title{
Factors Militating Against Safe Driving On Nigeria Roads: Lagos - Ibadan Expressway, As a Case Study
}

\author{
Fasanmade, P. A ${ }^{1}$; Rafiu, A. A ${ }^{2}$; Oladeji, A.O ${ }^{3}$. \\ Department of Civil, The Polytechnic, Ibadan, Adeseun Ogundoyin Campus, Nigeria. \\ Department of Mathematics \& Statistics, The Polytechnic, Ibadan, Adeseun Ogundoyin Campus, Nigeria. \\ Department of Purchasing and Supply, The Polytechnic, Ibadan, Adeseun Ogundoyin Campus, Nigeria.
}

Abstract: Despite all the efforts made by various arms of the government to ensure safety of human and material on the Nigeria roads, a lot of accidents still occur day in and day out on the roads. This paper analyses the route causes of the of the accidents in the order of their severities. The causes range lack of maintenance of the road infrastructures like roads bridges and drainages others are human errors and vehicular problems. However, the analyses showed that, human errors carried a very high percentage when compared with the other parameters. Recommendations were made in minimizing the rate to a very low level.

Key words: infrastructure, maintenance, human errors, correlation, natural phenomenon,

\section{Introduction}

The Federal Government of Nigeria in its National Transport Policy (1993), allotted a total of $85.25 \%$ of the transport budget on Road transport alone as compared with $4.15 \%$ on Air transport, $1.38 \%$ on Railway and $9.22 \%$ on Ports. Despite the huge amount spent on the Road transport, a lot of lives are being lost every day on the roads, for instance, the policy stated that Nigeria has the second highest accident rate in the world. The accident fatality rate are about 2 to 3 times those of the other African countries and 30 to 40 times higher than the rates in industrialized countries like USA or UK. Road accidents now account for notified deaths than all major communicable diseases combined (National Transport Policy, 1993).

It is therefore important that, solutions are pursued and the very best use is made of facilities such as human, technical and institutional capacity responsible for transport policy and implementation to work assiduously to avert the ugly trend of avoidable fatal accident in the country. A major aspect to be looked into is the maintenance of roads, by the institution responsible to it. Hence, a road agency needs an effective management information system to monitor road conditions and act promptly to repair the damaged portions. (Harral and Raiz, 1998). As rightly noted, by Ikya ( 1993) transportation is an essential element in the functionality of any society though the economic cost of goods and lives of poor roads maintenance are borne primarily by road user (Haggie, 1995). It is pertinent to note that the whole nation suffer the impact on the long run. The nature of transportation system in the area under study, calls for the need to change road geometry to cope with the road traffic volume weight/axle loading (Adesanya, 1991). This will prolong the life span of the roads.

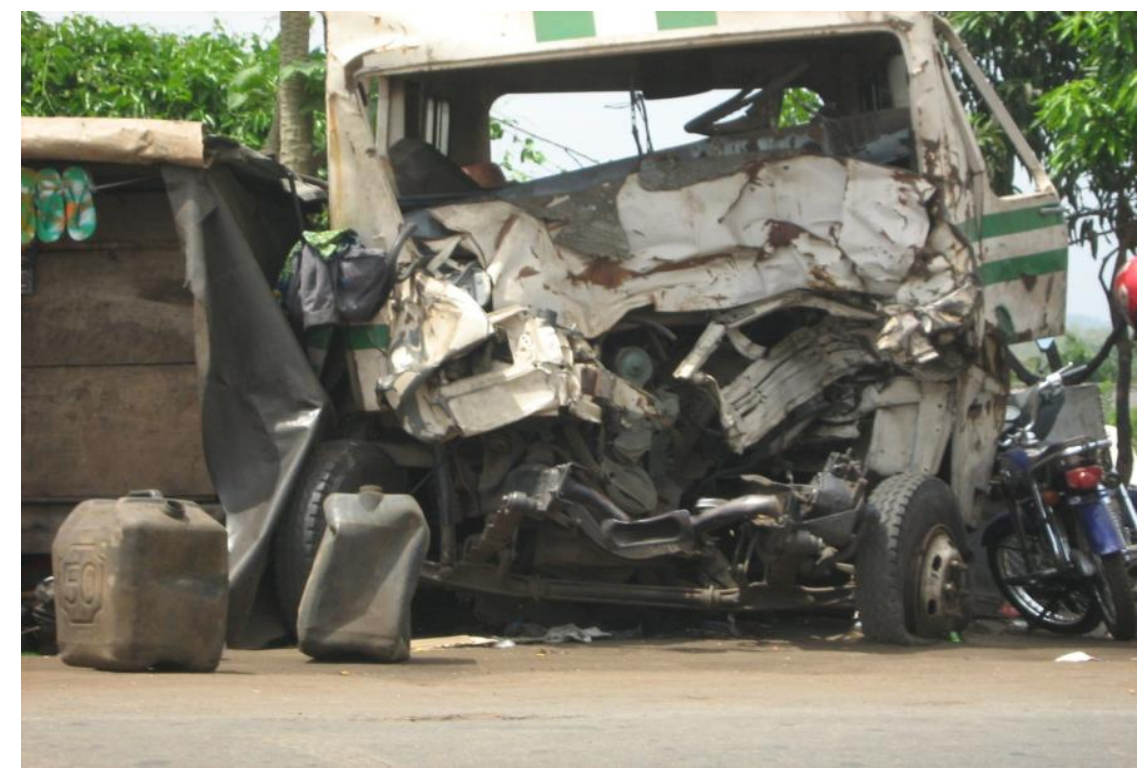

Fig 1. Accident vehicle (captured by the author) 


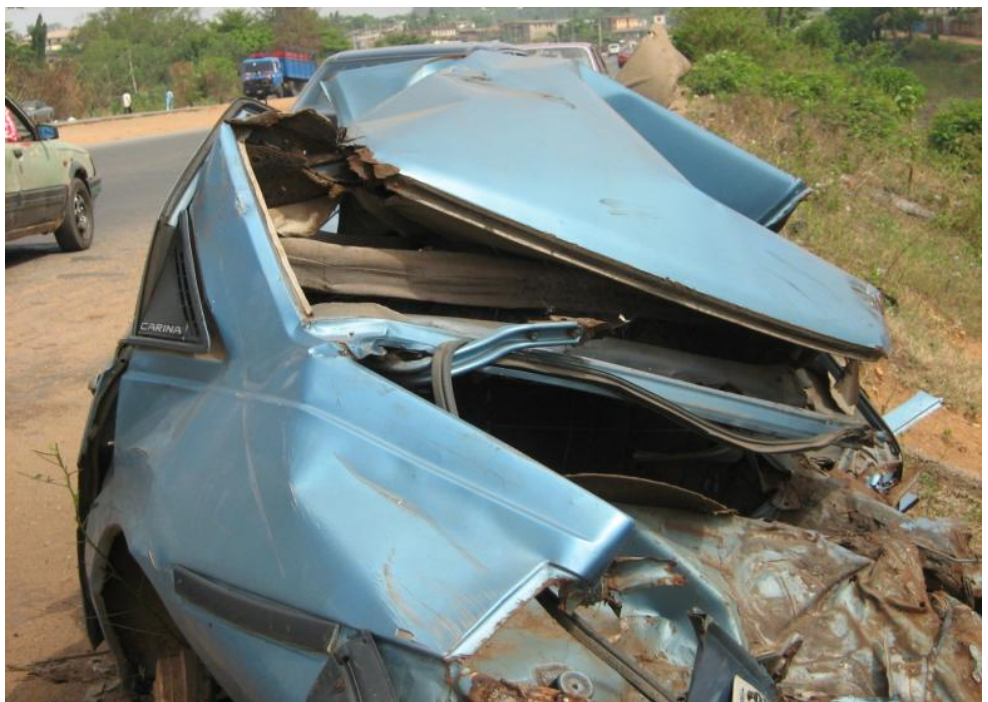

C1 Safety Engineering

Fig 2 . Accident vehicle (captured by the author)

C2 Road Condition Summary

Table 1 First Quarter Report, 2011

\begin{tabular}{|c|c|c|c|c|c|}
\hline $\mathbf{S} / \mathbf{N}$ & ROUTE & $\begin{array}{l}\text { ROAD SEGMENT SPECIFY } \\
\text { KM \& LAND MARK }\end{array}$ & $\begin{array}{l}\text { NATURE OF } \\
\text { DEFEC }\end{array}$ & & ACTION TAKEN \\
\hline 1. & $\begin{array}{l}\text { IB-LAG/LAG- } \\
\text { IB }\end{array}$ & $\begin{array}{l}\text { OPPOSITE ACCESS } \\
\text { CATHEDERAL CHURCH } \\
\text { KM1 }\end{array}$ & $\begin{array}{l}\text { POT-HOLES \& } \\
\text { ROUGH SURFACE }\end{array}$ & $\begin{array}{l}\text { LEFT \& } \\
\text { RIGHT }\end{array}$ & $\begin{array}{l}\text { THE POTHOLES } \\
\text { FILLED RECENTLY } \\
\text { HAVE RESURFACED } \\
\text { AGAIN }\end{array}$ \\
\hline 2. & LAG-IB & ARAMED & ROUGH SURFACE & $\begin{array}{l}\text { LEFT \& } \\
\text { RIGHT }\end{array}$ & $\begin{array}{l}\text { REQUIRE MAJOR } \\
\text { REPAIRS \& LAYING OF } \\
\text { ASPHALT }\end{array}$ \\
\hline 3. & IB-LAG & $\begin{array}{l}\text { HIGH ROCK MOTEL IWO } \\
\text { ROAD KM2 }\end{array}$ & ROUGH SURFACE & $\begin{array}{l}\text { LEFT \& } \\
\text { RIGHT }\end{array}$ & $\begin{array}{l}\text { FEMA HAS BEEN } \\
\text { OFFICIALLY } \\
\text { INFORMED }\end{array}$ \\
\hline 4. & $\begin{array}{l}\text { IB-LAG/LAG- } \\
\text { IB }\end{array}$ & $\begin{array}{l}\text { IWO ROAD 50MTRS TO } \\
\text { OVERHEAD BRIDGE OJO- } \\
\text { RD. }\end{array}$ & $\begin{array}{l}\text { POTHOLES, } \\
\text { ROUGH SURFACE }\end{array}$ & $\begin{array}{l}\text { LEFT \& } \\
\text { RIGHT }\end{array}$ & $\begin{array}{l}\text { LAYING OF ASPHALT } \\
\text { BY FERMA }\end{array}$ \\
\hline 5. & LAG-IB & KOBI AREA KM5 & ROUGH SURFACE & $\begin{array}{l}\text { LEFT \& } \\
\text { RIGHT }\end{array}$ & $\begin{array}{l}\text { REQUIRED REPAIRS \& } \\
\text { LAYING OF ASPHALT } \\
\text { BY FERMA }\end{array}$ \\
\hline 6. & $\begin{array}{l}\text { LAG-IB/IB- } \\
\text { LAG }\end{array}$ & KM 4 SOKA BRIDGE & $\begin{array}{l}\text { NO RAIL-GUIDE \& } \\
\text { BRIDGE-SPACER } \\
\text { PULLED OFF }\end{array}$ & $\begin{array}{l}\text { LEFT \& } \\
\text { RIGHT }\end{array}$ & $\begin{array}{l}\text { POTHOLES AND } \\
\text { ROUGH SURFACE } \\
\text { WAS REHABILITATED } \\
\text { BY FERMA }\end{array}$ \\
\hline 7. & IB-LAG & KM 8 OPPOSITE BAT & $\begin{array}{l}\text { POTHOLES \& } \\
\text { ROUGH SURFACE }\end{array}$ & $\begin{array}{l}\text { LEFT \& } \\
\text { RIGHT }\end{array}$ & $\begin{array}{l}\text { URGENT } \\
\text { REHABILITATION } \\
\text { REQUIRED BY } \\
\text { BICOURTNEY COMP. }\end{array}$ \\
\hline 8. & LAG-IB & WETTIP QUARRY KM19 & ROUGH SURFACE & $\begin{array}{l}\text { LEFT \& } \\
\text { RIGHT }\end{array}$ & $\begin{array}{l}\text { URGENT } \\
\text { REHABILITATION } \\
\text { REQUIRED }\end{array}$ \\
\hline 9. & URBAN & $\begin{array}{l}\text { OLORUNSOGO AKANRAN } \\
\text { RD. MOBIL/MTN OFFICE }\end{array}$ & $\begin{array}{l}\text { SCRAPPED AND } \\
\text { ROUGH SURFACE }\end{array}$ & $\begin{array}{l}\text { LEFT \& } \\
\text { RIGHT }\end{array}$ & $\begin{array}{l}\text { REHABILITATION } \\
\text { WORK IS ON-GOING } \\
\text { AND YET TO REACH } \\
\text { COMPLETED STAGE } \\
\text { BY OYO ROAD } \\
\text { MAINTENANCE } \\
\text { AGENCY. }\end{array}$ \\
\hline 10 & IJEBU-ODE & MAMU VILLAGE IJEBU RD. & NARROW ROAD & $\begin{array}{l}\text { LEFT \& } \\
\text { RIGHT }\end{array}$ & $\begin{array}{l}\text { THERE IS NEED TO } \\
\text { DUALIZE THE ROAD } \\
\text { DUE TO HIGH } \\
\text { VEHICULAR } \\
\text { MOVEMENT, FMW } \\
\text { HAVE BEEN NOTIFIED } \\
\text { THROUGH FERMA. }\end{array}$ \\
\hline
\end{tabular}

Data collected from the Federal Road Safety commission, Toll gate. Ibadan end of the Ibadan- Lagos express road. 2011. 


\section{Result And Discussion}

Table 2 Data Analysis: Correlation Matrix

\begin{tabular}{|l|l|l|l|l|l|}
\hline & Y & X2 & X3 & X4 & X1 \\
\hline Y & 1 & -0.045 & 0.853 & 0.612 & 0.650 \\
\hline X2 & -0.045 & 1 & 0.387 & 0.034 & -0.522 \\
\hline X3 & 0.853 & 0.387 & 1 & 0.787 & 0.169 \\
\hline X4 & 0.612 & 0.034 & 0.787 & 1 & -0.088 \\
\hline X1 & 0.650 & -0.522 & 0.169 & -0.088 & 1 \\
\hline
\end{tabular}

The correlation coefficient within each pair of dependent and independent variables as found in the computer printout is given above in form of a matrix.

$\begin{array}{ccl}\text { Y } & \text { represents } & \text { Road Accidents } \\ \text { X2 } & \text { represents } & \text { Driver's Fault } \\ \text { X3 } & \text { represents } & \text { Bad Road } \\ \text { X4 } & \text { represents } & \text { Vehicular Fault } \\ \text { X1 } & \text { represents } & \text { Natural phenomena }\end{array}$

From the above matrix, there is a relationship between

(i) Road Accidents and Vehicular fault.

(ii) Road Accidents and Natural phenomena.

(iii) Road Accidents and Drivers fault

\section{Correlations}

/VARIABLES $=$ Y X2 X3 X4 X1

/PRINT=TWOTAIL NOSIG

/MISSING=PAIRWISE

Table 3 Correlations (Dataset 0)

\begin{tabular}{|c|c|c|c|c|c|c|}
\hline & & $\mathbf{Y}$ & X2 & $\mathrm{X3}$ & $\mathrm{X} 4$ & X1 \\
\hline $\mathbf{Y}$ & $\begin{array}{l}\text { Pearson Correlation } \\
\text { Sig. (2-tailed) } \\
\text { N }\end{array}$ & $\begin{array}{l}1 \\
4\end{array}$ & $\begin{array}{l}-.045 \\
.955 \\
4\end{array}$ & $\begin{array}{l}.853 \\
.147 \\
4\end{array}$ & $\begin{array}{l}.612 \\
.388 \\
4\end{array}$ & $\begin{array}{l}.650 \\
.350 \\
4\end{array}$ \\
\hline $\mathbf{X} 2$ & $\begin{array}{l}\text { Pearson Correlation } \\
\text { Sig. (2-tailed) } \\
\text { N } \\
\end{array}$ & $\begin{array}{l}-.045 \\
.955 \\
4 \\
\end{array}$ & $\begin{array}{l}1 \\
4 \\
\end{array}$ & $\begin{array}{l}.387 \\
.613 \\
4 \\
\end{array}$ & $\begin{array}{l}.034 \\
.966 \\
4 \\
\end{array}$ & $\begin{array}{l}-.522 \\
.478 \\
4 \\
\end{array}$ \\
\hline $\mathrm{X3}$ & $\begin{array}{l}\text { Pearson Correlation } \\
\text { Sig. (2-tailed) } \\
\text { N }\end{array}$ & $\begin{array}{l}.853 \\
.147 \\
4 \\
\end{array}$ & $\begin{array}{l}.387 \\
.613 \\
4 \\
\end{array}$ & $\begin{array}{l}1 \\
4 \\
\end{array}$ & $\begin{array}{l}.787 \\
.213 \\
4 \\
\end{array}$ & $\begin{array}{l}.169 \\
.831 \\
4 \\
\end{array}$ \\
\hline X4 & $\begin{array}{l}\text { Pearson Correlation } \\
\text { Sig. (2-tailed) } \\
\text { N }\end{array}$ & $\begin{array}{l}.612 \\
.388 \\
4 \\
\end{array}$ & $\begin{array}{l}.034 \\
.966 \\
4 \\
\end{array}$ & $\begin{array}{l}.787 \\
.213 \\
4 \\
\end{array}$ & $\begin{array}{l}1 \\
4\end{array}$ & $\begin{array}{l}-.088 \\
.912 \\
4\end{array}$ \\
\hline X1 & $\begin{array}{l}\text { Pearson Correlation } \\
\text { Sig. (2-tailed) } \\
\text { N }\end{array}$ & $\begin{array}{l}.650 \\
.350 \\
4 \\
\end{array}$ & $\begin{array}{l}-.522 \\
.478 \\
4 \\
\end{array}$ & $\begin{array}{l}.169 \\
.831 \\
4 \\
\end{array}$ & $\begin{array}{l}-.088 \\
.912 \\
4\end{array}$ & $\begin{array}{l}1 \\
4 \\
\end{array}$ \\
\hline
\end{tabular}

\section{REGRESSION}

/MISSING LISTWISE

/STATISTICS COEFF OUTS R ANOVA

/CRITERIA=PIN (.05) POUT (.10)

/NOORIGIN

/DEPENDENT Y

Regression

/METHOD=ENTER X1 X2 X3 X4

(Dataset 0)

Table 4. Variables Entered/Removed ${ }^{\text {b }}$

\begin{tabular}{|l|l|l|l|}
\hline Model & Variables Entered & $\begin{array}{l}\text { Variable } \\
\text { Removed }\end{array}$ & method \\
\hline 1 & $\mathrm{X} 4, \mathrm{X} 2, \mathrm{X}^{\mathrm{a}}$ & & Enter \\
\hline
\end{tabular}

a. Tolerance $=.000$ limits reached.

b. Dependent Variable: Y 
Model Summary

Table 5

\begin{tabular}{|l|l|l|l|l|}
\hline Model & R & R Square & $\begin{array}{l}\text { Adjusted R } \\
\text { Square }\end{array}$ & $\begin{array}{l}\text { Std. Error of the } \\
\text { Estimate }\end{array}$ \\
\hline 1 & $1.000^{\mathrm{a}}$ & 1.000 & & \\
\hline
\end{tabular}

a. Predictors: (Constant), X4, X2, X1

Table 6. ANOVA ${ }^{\mathrm{b}}$

\begin{tabular}{|l|l|l|l|l|l|}
\hline Model & Sum of Squares & df & Mean Square & F & Sig. \\
\hline 1 Regression & 5068.750 & 3 & 1689.583 & & \\
Residual & .000 & 0 & & \\
$\quad$ Total & 5068.750 & 3 & & \\
\hline
\end{tabular}

a. Predictors: (Constant), X4, X2, X1

b. Dependent Variable: Y

\section{Coefficients $^{\mathrm{a}}$}

Table 7

\begin{tabular}{|l|ll|l|l|l|}
\hline \multirow{4}{*}{ Model } & \multicolumn{2}{|l|}{ Unstandardized Coefficients } & Standardized & & \\
\cline { 2 - 5 } & B & Std. Error & Coefficients & & \\
& & & Beta & T & Sig. \\
\hline 1 (Constant), & -6.451 & .000 & .027 &. &. \\
X4 & 1.327 & .000 & .417 &. &. \\
X2 & 2.142 & .000 & .679 &. &. \\
X1 & 1.873 & .000 &. &. \\
\hline
\end{tabular}

a.

Dependent Variable: Y

\section{Excluded Variables ${ }^{b}$}

Table 8

\begin{tabular}{|l|l|l|l|l|l|}
\hline Model & Beta In & t & Sig. & Partial Correlation & $\begin{array}{l}\text { Collinearity Statistics } \\
\text { Tolerance }\end{array}$ \\
\hline $1 \quad \mathrm{X} 3$ & $\mathrm{a}$ &. &. &. & 000 \\
\hline
\end{tabular}

a. Predictors in the Model : (Constant), X4, X2, X1

b. Dependent Variable: Y

\section{FACTOR}

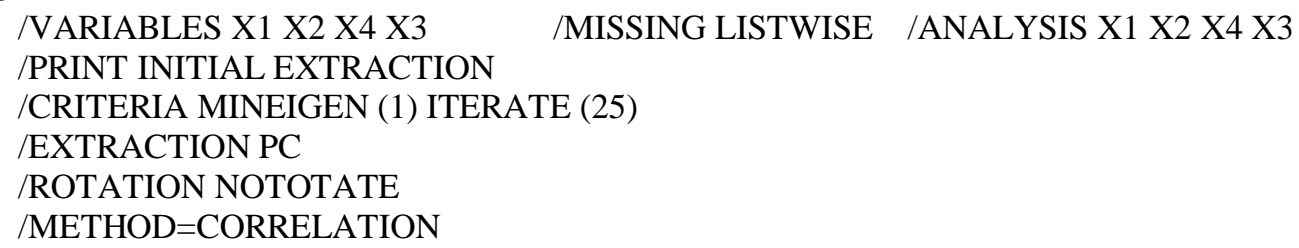

Factor Analysis

(Data Set 0)

\section{Communalities}

Table 9

\begin{tabular}{|l|l|l|}
\hline & Initial & Extraction \\
\hline $\mathrm{X} 1$ & 1.000 & .796 \\
$\mathrm{X} 2$ & 1.000 & .793 \\
$\mathrm{X} 4$ & 1.000 & .821 \\
$\mathrm{X} 3$ & 1.000 & .950 \\
\hline
\end{tabular}

Extraction Method: Principal Component Analysis.

Table 10 Total Variance Explained

\begin{tabular}{|c|c|c|c|c|c|c|}
\hline \multirow{2}{*}{ Component } & \multicolumn{3}{|c|}{ Initial Eigenvalues } & \multicolumn{3}{|c|}{ Extraction Sums of Squared Loadings } \\
\hline & Total & $\%$ of Variance & Cumulative \% & Total & $\%$ ff Variance & Cumulative \% \\
\hline 1 & 1.909 & \begin{tabular}{l|l} 
& 47.716
\end{tabular} & 47.716 & 1.909 & \begin{tabular}{|l|l|} 
& 47.716 \\
\end{tabular} & 47.716 \\
\hline 2 & 1.451 & 36.273 & 83.989 & 1.451 & 36.273 & 83.989 \\
\hline 3 & .640 & 16.011 & 100.000 & & & \\
\hline 4 & $-2.34 \mathrm{E}-016$ & $-5 \mid 85 E-0.15$ & 100.000 & & & \\
\hline
\end{tabular}

Extraction Method: Principal Component Analysis. 


\section{Component Matrix ${ }^{\mathrm{a}}$}

Table 1

\begin{tabular}{|l|r|r|}
\hline \multirow{2}{*}{} & \multicolumn{2}{|c|}{ Component } \\
\cline { 2 - 3 } X1 1 & \multicolumn{2}{|c|}{} \\
$\mathrm{X} 2$ & -.228 & .862 \\
$\mathrm{X} 4$ & .553 & -.698 \\
$\mathrm{X} 3$ & .839 & .342 \\
& .920 & .321 \\
\hline
\end{tabular}

Extraction Method: Principal Component Analysis

a. 2 components extracted.

Also, there is a relationship between vehicular fault and Natural phenomena.

There is a low relationship between Bad Road and Vehicular fault as well as Driver's fault and Vehicular fault. Furthermore, there is a very low relationship between Bad Road and Natural phenomena i.e. 3\% of the Road Accidents are caused by Bad Road and Natural phenomena. This implies that Natural phenomena like Road Traffic Violation, Obstruction, occurs most often on Good Road than Bad Road.

The correlation matrix also shows to us that there is no relationship between.

(i) Road Accidents and Bad Road.

This implies that Bad Road don't often cause Road Accidents. There are more road Accidents on Good Road than Bad road as a result of over-speeding by most drivers. But this does not mean that our Bad Road should not be repair by Governments as combination of Bad Road and other factors like vehicular fault, Natural phenomena lead to Road Accidents with a percentage of $39 \%$ and $3 \%$ respectively.

(ii) Drivers fault and Bad Road.

This implies that bad road has nothing to do with drivers fault. What constitute drivers fault can also occur on Good Road. This result conforms with reality.

(iii) Driver fault and Natural phenomena.

From the calculations and analysis so far carried out in this write-up it could be seen that three (3) out of the four (4) independent variables have relationship with Road Accidents i.e. vehicular fault, Drivers fault and Natural phenomena.

From the analysis, however, bad road has no relationship with road accidents. This may be so, because the drivers know that the roads are bad, therefore they will be naturally force to be careful. This means that the pot holes, sharp-bend, rough surfaces will force them to slowdown (non-over speeding). The few accidents that do occur on Bad Road accounts for the $3 \%$ earlier mentioned.

\section{Vehicular fault}

This has the highest percentage of $85 \%$ contribution to Road Accident. Most vehicles plying our road are supposed to be off-Road due to their rickety nature, poor vehicle conditions may be due to the country economic problem

Bad-brake conditions, use of bad tyres lack of inner/side mirrors, expired wind-screen, managing spare part instead of replacing them with better ones all constitutes vehicular fault.

The influx of fairly-used cars, most especially those rated lowest grade with cheaper rates constitute nuisance and pollution on our road and thereby caursing Road Accidents.

Drivers fault has the percentage of $65 \%$ contribution to Road Accidents. Some drivers are under age, unlicensed, suffering from one eye problem or the other, influence of alcohol, psychologically disturbed and illiteracy.

The Natural Phenomena such as over speeding, obstruction, Road Traffic violation etc constitutes $61 \%$ of what causes Road accidents. Part of the Natural phenomena that leads to Road accidents are those caused by Road safety officials Policemen through Road block at dangerous point on our roads.

Before we can effectively recommend ways of reducing road accidents, it is pertinent to first of all enumerate some causes as contained in Oyo State Police Headquarters and Federal Road Safety Commission files.

(i) Prevalence of inexperienced, illiterates unlicensed and under-age drivers.

(ii) Poor conditions of vehicles.

(iii) Escalating prices and non availability of spare parts which further aggravates poor conditions of vehicles.

(iv) Increase in number of automobiles and population which leads to overloading of vehicles and heavy density.

(v) Excessive speeding. 
(vi) Absence of neon sign to indicate danger zone.

(vii) Alcoholism

(viii) Lack of formal training for drivers.

(ix) Ease of obtaining driving licenses.

(x) Rush to make as much money as possible from passengers fares.

(xi) Poor conditions of roads.

(xii) Carelessness on the drivers' part.

(xiii) Wrong overtaking.

(xiv) Pedestrians fault

(xv) Passengers fault.

\section{Conclusion}

From the data analyses, most of the above mentioned points are contained in the our independent variables i.e. they have been summarized into the four independent variables.

Accidents are not usually caused by single variable, but by a combination of variables (Akanbi O.G. et al 2011).

\section{RECOMMENDATIONS}

Let us now recommend ways of reducing road accidents to a significant level The following recommendations are hereby suggested

1. Formal training should be given to drivers to provide sufficient amount of direct experience at controlling vehicles in protected areas and difficult situations.

2. Government can purchase enough buses for passengers to avoid rushing and the few they have should be well maintained. The buses as well as the cab purchased should be spread to all the local governments in the country i.e. it should not be dumped at only the capital city.

3. Government can encourage Nigerians (or through Private Public Partnership) to set up resort centers along the inter-city roads so that drivers can intermittently break their journey and refresh instead of sleeping on the wheel as a result of boredom or exhaustion.

4. Mobile courts should be dispatched to the highways and intercity roads to apprehend reckless drivers. This is so because it is not only the driver that will die in an accident, innocent passengers are mostly involved.

5. Federal Roads Safety Commission vehicle can be stationed at intervals on inter-city roads. The road block should be at a safe place. The commission should know that saving life of the citizenship supersedes making money for the commission.

6. The fact that the percentage of Road Accidents caused by bad road is less does not mean that our road should not be repaired and put in good condition. Some of the intercity busy roads can be turned into dual carriage way.

7. Most of the speed-breaker we have on our road be removed and replace by high-tech speed check as used by most advanced countries of the world.

8. Federal Government should place an immediate prohibition on the sale of alcoholic drinks at motor parks and major roads throughout the country.

9. Government to subsidize prices of spare parts of vehicles coming into the country.

10. The vehicle inspection officers to be vigilant and apprehend culprit whose vehicle constitute nuisance and pollution to the society.

11. Employers of labour can also help to reduce road accidents by paying accident bonus to their drivers at the end of the year to serve as a sort of encouragement and morale booster.

12. License issuance office should be centralized to the state capitals in order to maintain driving tests standard, check under-age, over-age, conduct eye test e.t.c.

\section{References}

[1]. Adesanya, A.O. 1991. Administration and provision of Roads in Ogun State, NISER Monograph Series No. 17

[2]. Akanbi, O. G, Charles-Owaba, O. E and Olaleye, A. E. 2011. Human factor in traffic accident in Lagos, Nigeria. Disaster prevention and management.Vol.18 no 4 2009. Pp397- 409. Emerald Group Publishing Limited, 0965-3562.

[3]. Federal Road Safety Commission. 2012. Toll Gate, Oyo State Command. Ibadan.

[4]. Harral, G. \& Raiz, A. 1988. Road Deterioration in Developing Countries: causes and Remedies, The World Bank, Washington D.C.

[5]. Haggie J.G. 1995. Management and Financing of Roads, an Agenda for Reform, World Bank, Washington D.C.

[6]. Ikya, S.G. 1993. Urban Passenger Transportation in Nigeria, Heinemann Educational Books (Nig.) Plc, Ibadan.

[7]. National Transport Policy 1993. Federal Ministry of Transport Main Doc. National Rolling Plan 1994-96, Vol. 1, Lagos. 